\title{
Sistem Informasi Pengolahan Data Kependudukan Pada Kantor Desa Sampean Berbasis Android
}

\author{
Muhamad Alda \\ Program Studi Sistem Informasi, STMIK Logika, Medan, Indonesia \\ E-mail: ${ }^{*}$ muhamadalda9@gmail.com
}

\begin{abstract}
Abstrak-Data penduduk merupakan data yang harus di rekam pada setiap kantor desa sekitar. Dengan adanya data penduduk, kantor desa dapat melakukan monitoring penduduk yang terdapat pada lingkungan tersebut. Selama ini, kantor desa sampean kecamatan sungai kanan kabupaten labuhan batu selatan, sumatera utara masih menggunakan aplikasi desktop dalam melakukan proses pengolahan data penduduk yaitu menggunakan aplikasi Microsoft Excel. Dengan cara tersebut masih terdapat beberapa masalah dan kendala yang terjadi, terutama waktu dan tenaga yang dikeluarkan pada saat melakukan distribusi data penduduk kepada pihak-pihak yang membutuhkan di kantor desa sampean. Tujuan dilakukannya penelitian ini adalah untuk merancang dan membangun sistem informasi pengolahan data penduduk berbasis android. Dengan adanya sistem informasi yang di rancang oleh penulis, diharapkan dapat membantu pihak kantor desa sampean dalam melakukan proses pengolahan data penduduk dan melakukan distribusi data penduduk secara mudah dan cepat melalui smartphone android. Sistem informasi dibangun dengan menggunakan aplikasi Kodular dan database Airtable.
\end{abstract}

Kata Kunci: Sistem Informasi, Data Penduduk, Kantor Desa Sampean, Android, Kodular, Airtable

Abstract-The population data is the data have to be in record in any office the villages around. With the citizens data, the village office can do monitoring inhabitant of which is found in the neighborhood. So far, the village office sampean kecamatan sungai kanan kabupaten labuhan batu selatan, north sumatra still use application desktop in doing processing the population data that is use application microsoft excel .In such a manner as there are still several problems and the obstacles, especially time and energy issued when their distribution data population in parties in need by the village office sampean. The purpose of he did this research is to design and construct information system the population data processing based android. With the information systems that in designed by the writer, is expected to help parties the village office sampean in doing processing the population data and do distribution the population data easily And rapidly through a smartphone android. Information system built by using application kodular and a database airtable

Keywords: Information System, Population Data, Village Office Sampean, Android, Kodular, Airtable

\section{PENDAHULUAN}

Di era sekarang teknologi sangat erat kaitannya dengan internet dan akses internet pun tidak hanya di akses pada komputer tetapi telah bisa di akses melalui smartphone yang semakin canggih, perkembangan internet sangat mempengaruhi kehidupan sosial serta cara berkomunikasi seseorang. Smartphone android memiliki fitur yang lengkap sehingga selain digunakan sebagai media hiburan,smartphone android dapat digunakan untuk pemenuhan kebutuhan informasi dan membantu dalam menyelesaikan berbagai macam permasalahan [1].

Penduduk merupakan objek yang sekaligus sebagai subjek dalam pembangunan nasional. Kebijaksanaan dibidang kependudukan bukan hanya mengenai jumlah dan kepadatan penduduk, arus imigrasi, kelahiran serta kematian tetapi juga kebijakan dalam hal mengendalikan pertumbuhan penduduk yang tinggi serta mengarahkan mobilitas dan sebaran penduduk yang lebih merata, terutama didaerah yang jarang penduduknya,Untuk mengatur jumlah penduduk yang diinginkan akan menimbulkan permasalahan sosial dan ekonomi. Pertambahan penduduk yang sangat besar akan mempengaruhi sarana dan prasarana pada bidang pendidikan, kesehatan, dan lain sebagainya [2].

Kantor desa sampean merupakan kantor desa yang berada di kecamatan sungai kanan, kabupaten labuhan batu selatan. Selama ini, dalam melakukan proses pengolahan data penduduk, kantor desa sampean masih menggunakan cara manual. Petugas kantor desa mencatat data - data penduduk pada sebuah buku dan melakukan pengolahan data pada buku tersebut. Dengan menggunakan cara seperti, masih terjadi beberapa masalah, seperti waktu dan tenaga yang dikeluarkan dalam melakukan proses pengolahan data tersebut. Selain itu, pada saat mencari data dan melihat laporan, petugas kantor desa juga mengalami kendala. Petugas harus melihat data penduduk satu persatu sehingga proses pencarian data penduduk tidak efektif dan efisien.

Tujuan dilakukannya penelitian ini adalah untuk merancang dan membangun sebuah sistem informasi kependudukan berbasis android yang dapat digunakan untuk membantu pihak kantor desa sampean dalam melakukan proses pengolahan data kependudukan secara cepat dan mudah melalui smartphone android

\section{METODE PENELITIAN}

Sistem informasi merupakan suatu kombinasi teratur dari orang-orang, hardware, software, jaringan komunikasi dan sumber daya data yang mengumpulkan, mengubah, dan menyebarkan informasi dalam sebuah organisasi [3]. Sistem informasi memiliki komponen atau blok, antara lain [4] :

a. Komponen input, merupakan data yang masuk ke dalam sistem informasi yang akan diproses lebih lanjut, termasuk metode dan media untuk menangkap data. 
b. Komponen model, terdiri atas kombinasi prosedur, logika dan model matematik yang digunakan untuk melakukan proses pengolahan data input serta data yang tersimpan pada basis data.

c. Komponen output, hasil dari keluaran dari sistem informasi berupa informasi yang berkualitas

d. Komponen teknologi, merupakan tool box dalam sistem informasi yang berfungsi untuk menerima input, menjalankan proses, menyimpan data, menghasilkan informasi dan melakukan distribusi dari informasi yang dihasilkan.

e. Komponen hardware, berfungsi sebagai media penyimpanan bagi sistem informasi untuk menampung data yang akan diolah dan informasi yang dihasilkan.

f. Komponen software, berfungsi sebagai tempat untuk mengolah, menghitung dan memanipulasi data yang telah tersimpan di basis data.

g. Komponen basis data, merupakan tempat kumpulan data yang saling terintegrasi anatar satu dengan yang lain, tersimpan diperangkat keras komputer dan memerlukan perangkat lunak untuk memprosesnya.

h. Komponen control, proses yang perlu dirancang dan diterapkan untuk meyakinkan bahwa suatu hal yang dapat merusak sistem dapat dicegah dan apabila terjadi kesalahan dapat segera diatasi.

Penduduk adalah warga negara Indonesia dan orang asing yang bertempat tinggal di Indonesia. Kependudukan berkaitan dengan jumlah, struktur, umur, jenis kelamin, agama, kelahiran, perkawinan, kehamilan dan lain sebagainya yang berhubungan dengan politik, ekonomi, sosial, dan budaya. Pengolahan data penduduk adalah suatu upaya yang dilakukan untuk mengarahkan perkembangan kependudukan dan pembangunan keluarga untuk mewujudkan penduduk tumbuh seimbang serta mengembangkan kualitas penduduk pada seluruh tingkatan penduduk. [5].

Android adalah sebuah sistem operasi yang dikembangkan untuk diimplementasikan pada perangkat mobile berbasis linux yang mencakup sistem operasi, middleware, dan aplikasi [6].

Fitur - fitur yang terdapat pada android adalah sebagai berikut [7] :

a. Kerangka aplikasi: memungkinkan untuk menggunakan dan menghapus komponen yang tersedia.

b. Dalvik mesin virtual: mesin virtual digunakan secara optimal untuk perangkat telepon seluler.

c. Grafik: grafik di 2D dan grafis 3D berdasarkan pustaka OpenGL.

d. SQLite: sebagai database.

e. Mendukung media: audio, video, dan berbagai format gambar.

f. GSM, Bluetooth, EDGE, 3G, 4G dan WiFi (tergantung piranti keras)

g. Kamera, Global Positioning System (GPS), kompas, NFC dan accelerometer (tergantung piranti keras)

Penelitian yang dilakukan oleh Angga Yudha P dkk pada penulisan karya ilmiahnya (Jurnal JSIKA) yang berjudul "Rancang Bangun Aplikasi Analisis Data Keluarga Miskin Berdasarkan Kriteria Badan Pusat Statistik (BPS) Di Desa Banaran Kabupaten Kediri” tahun 2016 masalah yang dihadapi adalah keterlibatan pemerintah dalam melakukan pendataan penduduk miskin, pemerintah desa mengalami kesulitan dalam proses pendataan tersebut. Proses pendataan masih dilakukan secara manual, yaitu data tingkat keluarga satu per satu dengan kemiskinan yang telah ditentukan oleh desa. Untuk membantu mengatasi permasalahan tersebut, penulis mengembangkan aplikasi dengan menggunakan Sistem Development Life Cycle (SDLC) dan terdapat empat belas kriteria kemiskinan dari Badan Pusat Statistik (BPS) yang digunakan sebagai indikator penilaian kemiskinan. Dengan adanya aplikasi ini diharapkan dapat membantu pemerintah desa untuk mewujudkan misi desa dalam melakukan pendataan penduduk miskin [8].

Penelitian yang dilakukan oleh Martua Sihaloho, Eka Wati Sriwahyuni, Rilus A. Kinseng pada penulisan karya ilmiahnya (Jurnal Sosiologi Pedesaan) yang berjudul "Perubahan Struktur Agraria, Kemiskinan,Dan Gerak Penduduk: Sebuah Tinjauan Historis" tahun 2016 masalah yang dihadapi adalah Masyarakat miskin pada pedesaan yang memilih untuk menjadi pelaku migran sebagai upaya dalam mengatasi permasalahan ekonomi. Pelaku migran pada akhirnya berkontribusi secara nasional berupa remiten. Hasil remiten (khususnya ekonomiuang) dapat memenuhi kebutuhan keluarga dan mampu menjadi asset (misal lahan dan rumah) untuk dijadikan modal bahkan ke arah perubahan struktur agraria lokal. Hasil dari beberapa penelitian menunjukkan peningkatan kesejahteraan keluarga pelaku migrasi [9].

Tahapan yang dilakukan dalam penelitian ini adalah sebagai berikut :

1. Perumusan Masalah

Pada tahap ini penulis merumuskan ruang lingkup masalah yang akan dibahas pada penelitian ini yaitu mengenai sistem pengolahan data penduduk pada desa Sampean, Kecamatan Sungai Kanan, Kabupaten Labuhan Batu Selatan dan menentukan alternatif pemecahan masalah tersebut

2. Studi Literatur

Pada tahap ini penulis melakukan apa yang disebut dengan kajian pustaka yaitu mempelajari buku-buku referensi, artikel pada situs-situs yang relevan dengan penelitian. Tujuannya adalah untuk mendapatkan pemahaman teori dan konsep tentang masalah yang diteliti.

3. Pengumpulan Data

Pada tahap ini penulis melakukan pengumpulan data. Pengumpulan data merupakan tahapan dalam proses penelitian yang penting, dimana penulis harus mendapatkan data yang dibutuhkan dalam merancang sistem dan pembangunan sistem. Adapun metode yang digunakan penulis dalam mengumpulkan data adalah sebagai berikut: 
1. Observasi

Penulis melakukan pengamatan langsung pada tempat penelitian yaitu Kantor Desa Sampean, Kecamatan Sungai Kanan, Kabupaten Labuhan Batu Selatan untuk mengamati proses pengolahan data penduduk dan mencari permasalahan yang terjadi pada proses tersebut.

2. Wawancara

Penulis melakukan tanya jawab langsung pada pihak terkait mengenai proses pengolahan data penduduk pada Kantor Desa Sampean, Kecamatan Sungai Kanan, Kabupaten Labuhan Batu Selatan dan permasalahan yang terjadi

4. Analisis Kebutuhan

Pada tahap ini dilakukan analisis kebutuhan dari sistem yang akan dirancang meliputi data-data yang dibutuhkan dalam perancangan dan pembangunan sistem

5. Desain dan Implementasi

Pada tahap dilakukan perancangan dan pembangunan sistem berdasarkan kebutuhan yang telah ditentukan pada tahapan sebelumnya.

6. Pengujian Sistem

Pada tahap ini dilakukan pengujian keseluruhan dari sistem yang telah dirancang,dengan mengintegrasikan unit-unit sistem tersebut sehingga menjadi sebuah sistem yang lengkap.

\section{HASIL DAN PEMBAHASAN}

\subsection{Analisis Sistem Berjalan}

Pada tahapan ini, penulis melakukan analisis sistem pengolahan data penduduk yang telah berjalan pada Kantor Desa Sampean. Penulis mencari permasalahan yang terjadi pada sistem pengolahan data tersebut.

Proses pengolahan data yang sedang berjalan pada Kantor Desa Sampean masih menggunakan cara yang semi manual. Dalam melakukan proses pengolahan data, staff Kantor Desa Sampean menggunakan aplikasi Microsoft Excel. Dengan melakukan cara seperti ini, masih terdapat beberapa kendala yang terjadi, antara lain :

1. Staff Kantor Desa Sampean mengalami kesulitan saat proses penyampaian informasi penduduk kepada kepala desa atau bagian lainnya. Staff harus menyimpan data penduduk tersebut pada media penyimpanan eksternal dan memberikannya kepada kepala desa dan bagian lainnya.

2. Staff membutuhkan waktu dan tenaga yang banyak pada saat memberikan media penyimpanan tersebut kepada kepala desa ataupun bagian lainnya, dikarenakan jarak antar ruangan

3. Membutuhkan biaya yang besar dalam penyediaan perangkat komputer dan supply listrik

4. Proses pengolahan akan terkendala, jika listriik mati pada Kantor Desa Sampean.

5. Hanya bisa diakses secara offline pada perangkat komputer yang telah ditentukan.

\subsection{Analisis Kebutuhan Sistem}

Berdasarkan hasil dari analisis sistem yang telah berjalan, penulis menentukan solusi yang dapat digunakan untuk menyelesaikan permasalahan tersebut. Penulis merancang dan membangun sebuah sistem informasi pengolahan data penduduk berbasis android pada Kantor Desa Sampean. Sistem informasii ini dapat membantu staff Kantor Desa Sampean dalam melakukan proses pengolahan data penduduk dan membantu kepala desa atau bagian lainnya dalam memperoleh informasi mengenai data penduduk secara mudah dan cepat melalui smartphone android.

\subsection{Perancangan Sistem}

Tools yang digunakan dalam membuat rancangan sistem adalah Diagram UML (Unified Modeling Languange). UML (Unified Modeling Language) merupakan bahasa visual yang digunakan untuk melakukan pemodelan dan komunikasi mengenai sebuah sistem dengan menggunakan diagram dan teks-teks pendukung [10].

\section{Use Case Diagram}

Use Case diagram digunakan untuk menggambarkan interaksi apa saja yang bisa dilakukan oleh user kepada sistem. Sistem informasi dibangun secara multiuser, sehingga sistem informasi ini dapat diakses oleh dua user yang berbeda yaitu staff yang berperan sebagai admin dan kepala desa atau bagian lainnya Kantor Desa Sampean. Setiap user memiliki hak akses yang berbeda. Staff Kantor Desa Sampean dapat melakukan pengolahan data penduduk sedangkan kepala desa atau bagian liannya hanya dapat melihat informasi data penduduk 
Volume 4, Nomor 1, Januari 2020, Page 1-8

ISSN 2614-5278 (media cetak), ISSN 2548-8368 (media online)

Available Online at https://ejurnal.stmik-budidarma.ac.id/index.php/mib DOI 10.30865/mib.v4i1.1716

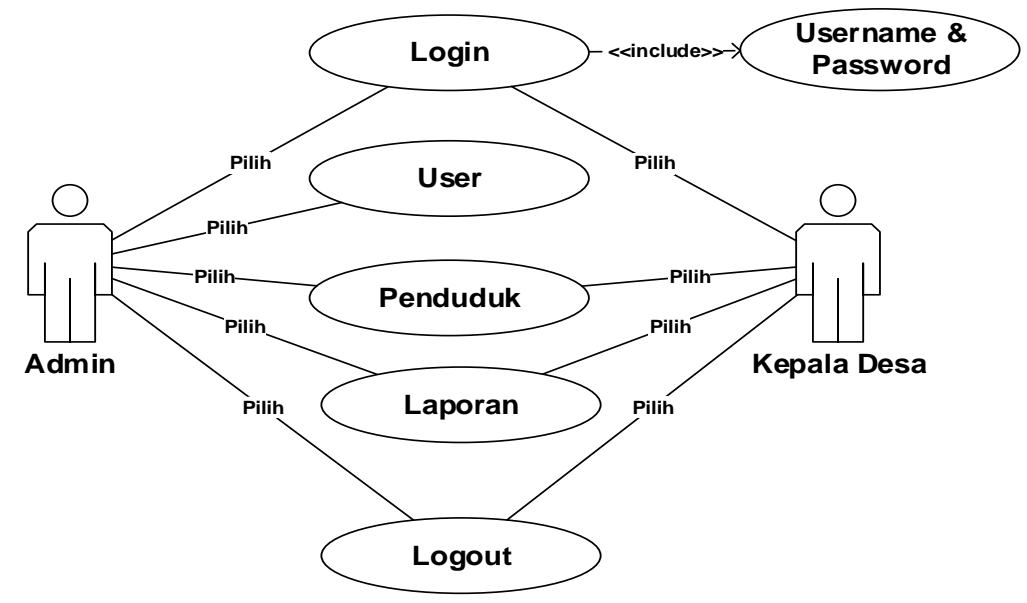

Gambar 1. Use Case Diagram Pengolahan Data Penduduk

\section{Sequence Diagram}

Sequence Diagram menggambarkan bagaimana user melakukan interaksi dengan sistem informasi untuk mendapatkan informasi yang dibutuhkan.Sequence diagram pada sistem informasi pengolahan data penduduk dibedakan menjadi dua jenis, yaitu sequence diagram admin (Staff Kantor Desa Sampean) dan sequence diagram user (Kepala desa atau bagian lainnya)

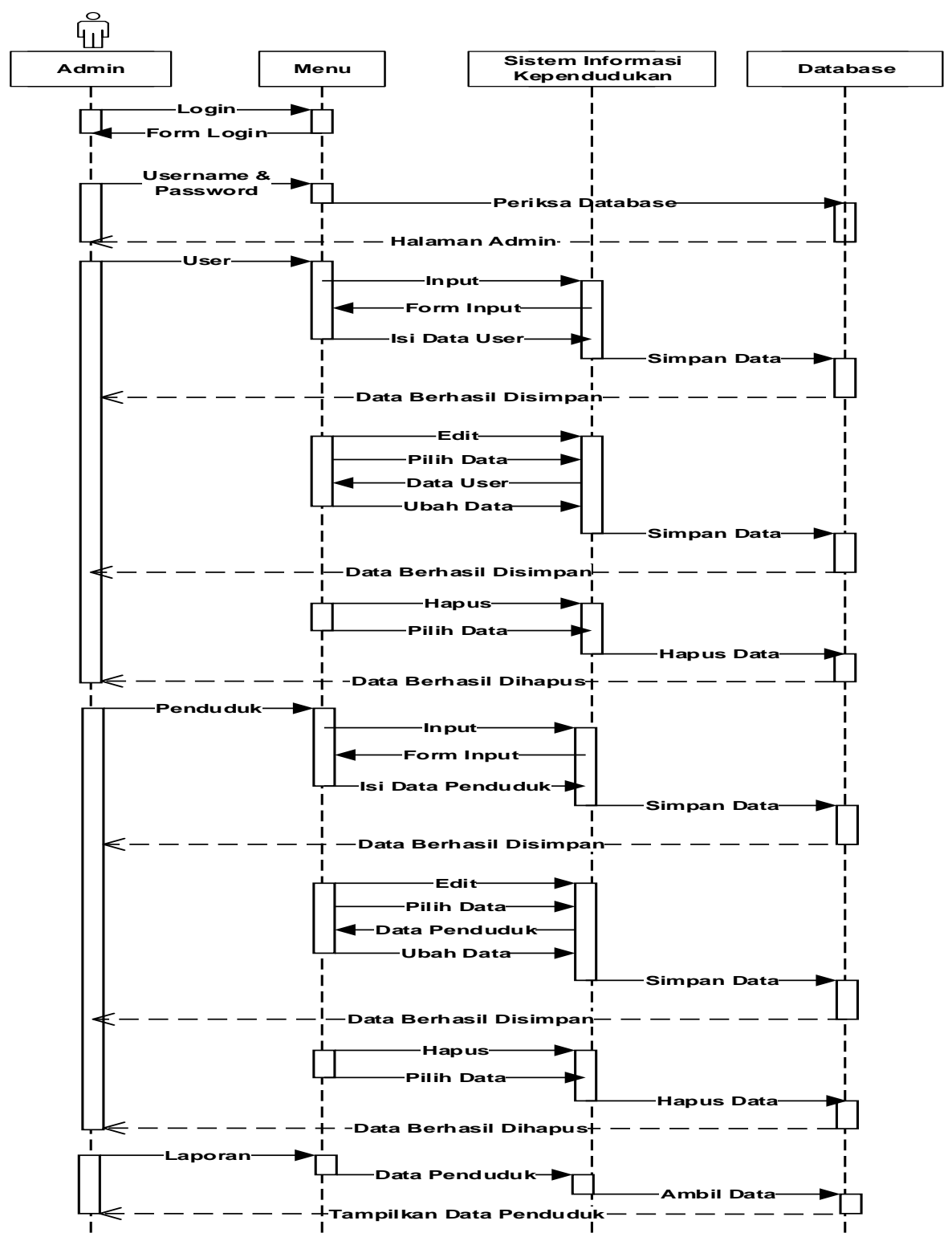

Gambar 2. Sequence Diagram Admin 
JURNAL MEDIA INFORMATIKA BUDIDARMA

Volume 4, Nomor 1, Januari 2020, Page 1-8

ISSN 2614-5278 (media cetak), ISSN 2548-8368 (media online)

Available Online at https://ejurnal.stmik-budidarma.ac.id/index.php/mib DOI $10.30865 /$ mib.v4i1.1716

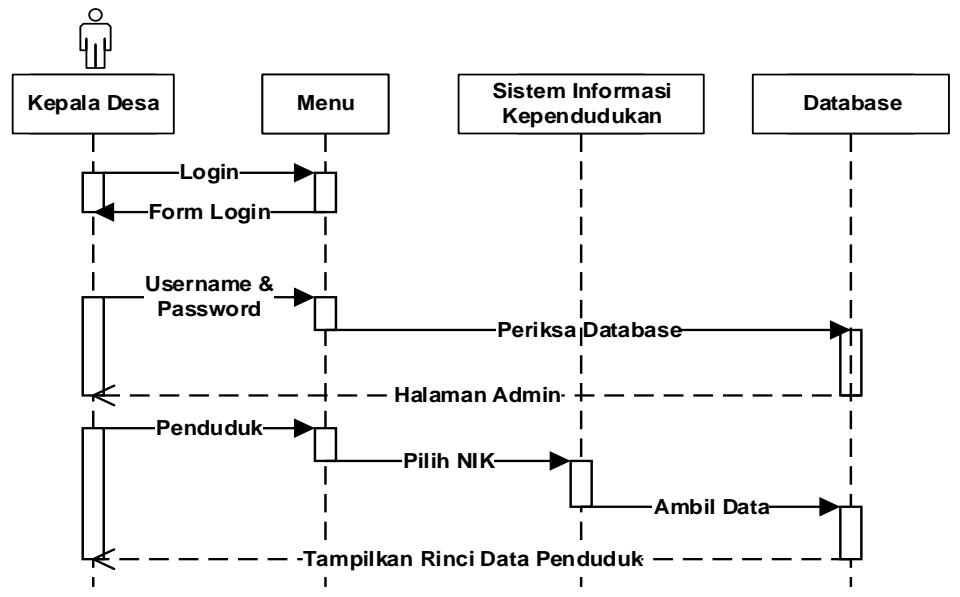

Gambar 3. Sequence Diagram User

\section{Activity Diagram}

Activity diagram atau disebut juga dengan diagram aktivitas, merupakan diagram yang menggambarkan aktivitas dari sebuah sistem, bagaimana sistem melakukan suatu aktivitas dalam menjalankan fungsi tertentu. activity diagram pada sistem informasi pengolahan data penduduk terbagi menjadi dua jenis, yaitu activity diagram admin (Staff Kantor Desa Sampean) dan activity diagram user (Kepala desa atau bagian lainnya).

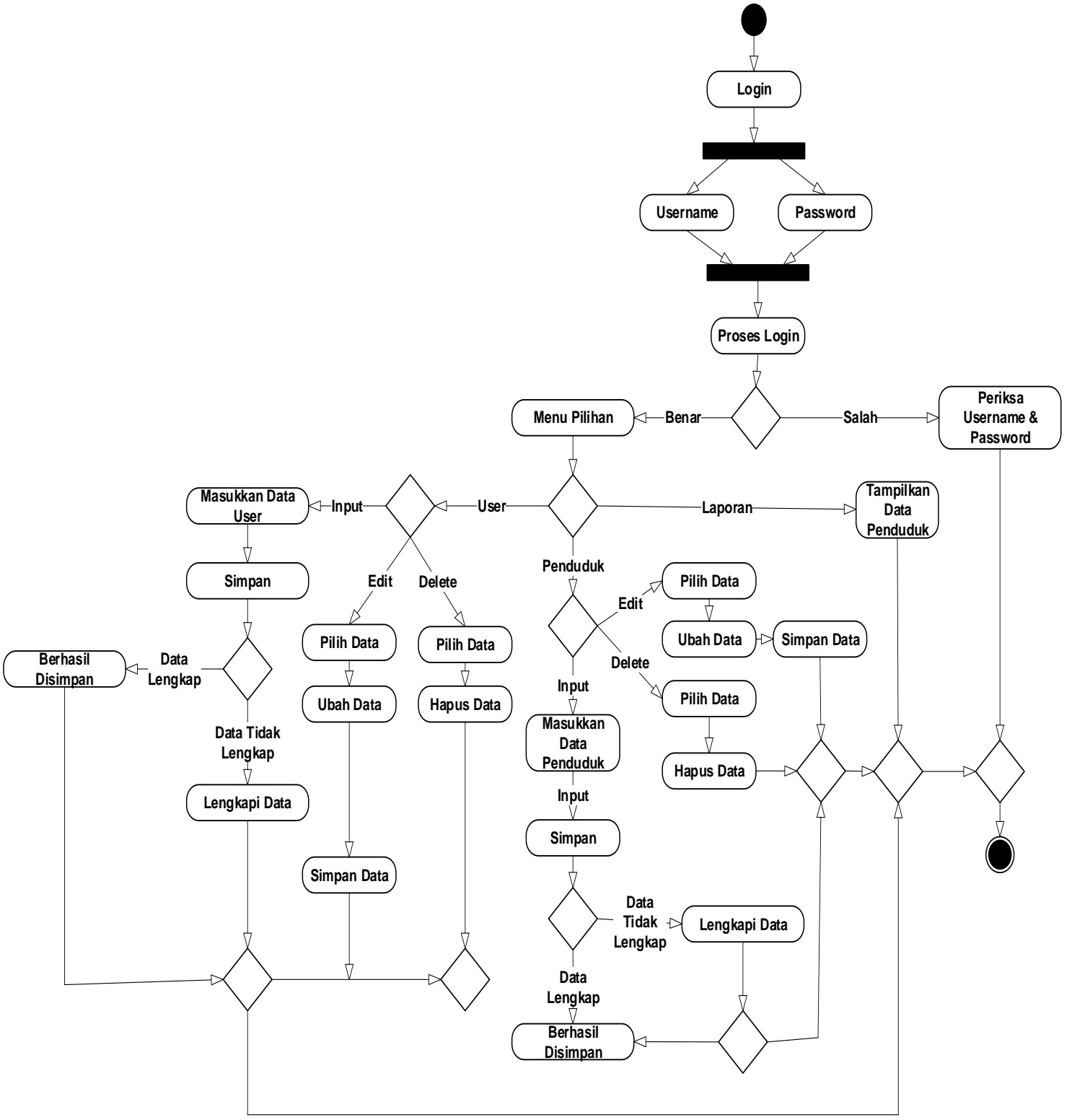

Gambar 4. Activity Diagram Admin 
JURNAL MEDIA INFORMATIKA BUDIDARMA

Volume 4, Nomor 1, Januari 2020, Page 1-8

ISSN 2614-5278 (media cetak), ISSN 2548-8368 (media online)

Available Online at https://ejurnal.stmik-budidarma.ac.id/index.php/mib DOI 10.30865/mib.v4i1.1716

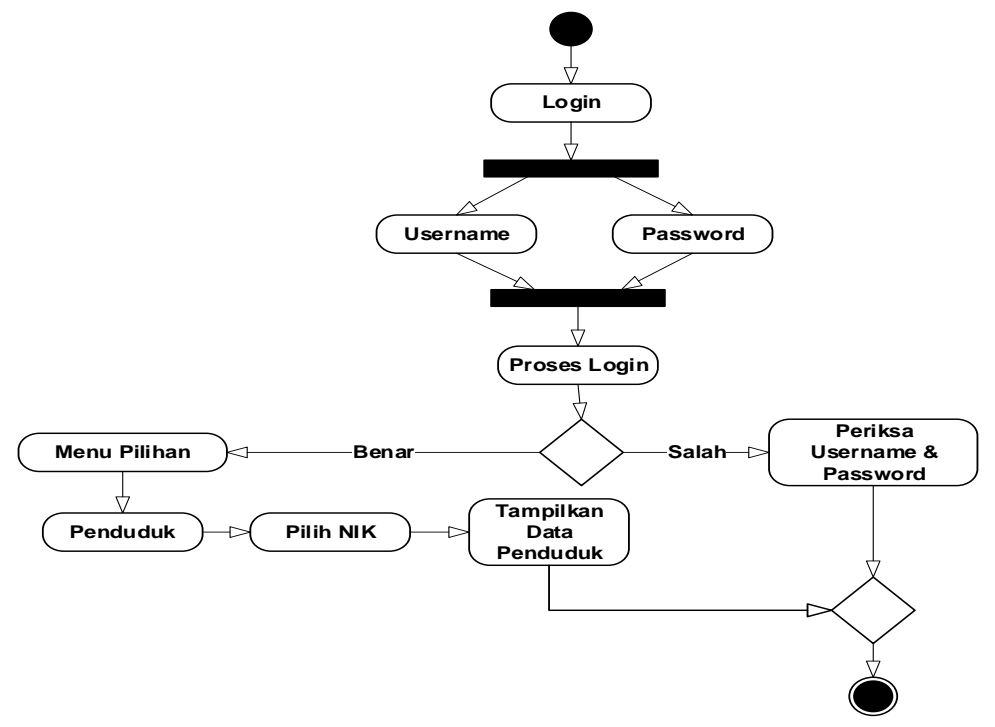

Gambar 5. Activity Diagram User

\section{Class Diagram}

Class Diagram merupakan diagram yang menggambarkan hubungan dari setiap class atau tabel yang terdapat pada database Sistem informasi pengolahan data penduduk Kantor Desa Sampean. Class atau tabel pada sistem informasi pengolahan data penduduk Kantor Desa Sampean terdiri dari tabel admin, tabel user, dan tabel penduduk.

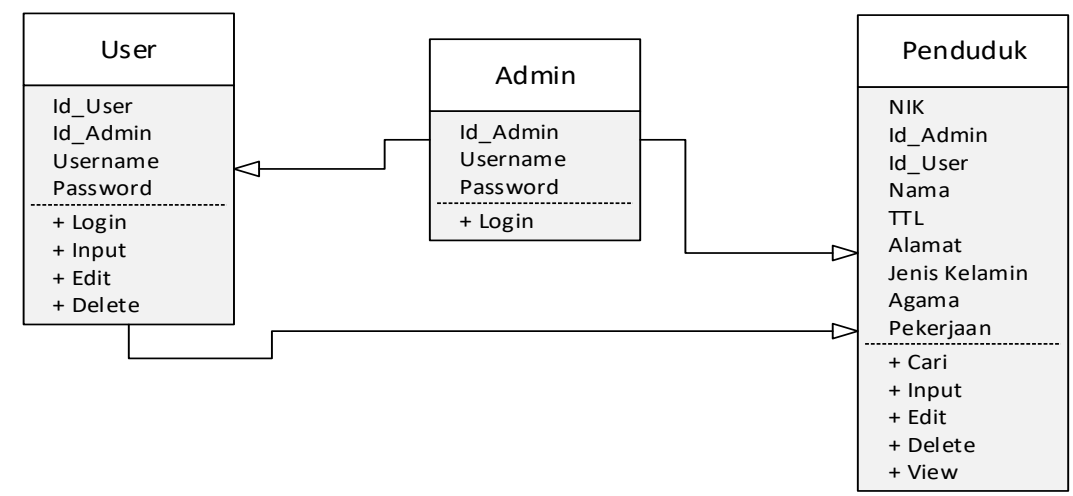

Gambar 6. Class Diagram

\subsection{Implementasi Sistem Informasi}

Sistem informasi kependudukan dibangun secara multiuser, sehingga halaman dari sistem informasi yang telah dibangun terlihat dari sisi admin pada sistem informasi kependudukan terdiri dari halaman utama, halaman user dan halaman kependudukan

\section{a. Tampilan Halaman Utama}

Halaman utama merupakan halaman awal yang muncul saat user menggunakan sistem informasi kependudukan. Admin dan user memiliki tampilan halaman utama yang sama.

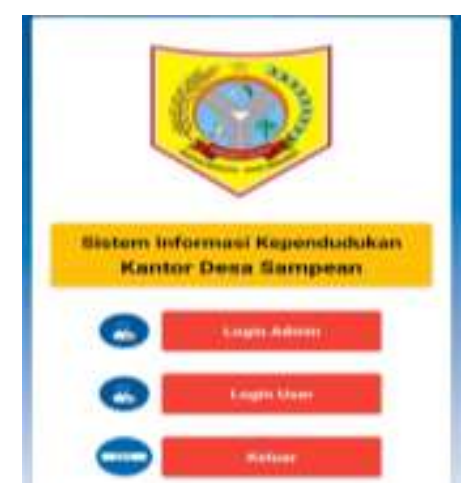

Gambar 7. Tampilan Halaman Utama 


\section{JURNAL MEDIA INFORMATIKA BUDIDARMA}

Volume 4, Nomor 1, Januari 2020, Page 1-8

ISSN 2614-5278 (media cetak), ISSN 2548-8368 (media online)

Available Online at https://ejurnal.stmik-budidarma.ac.id/index.php/mib DOI 10.30865/mib.v4i1.1716

\section{b. Tampilan Halaman Login}

Pada halaman ini, admin memasukkan username dan password untuk melakukan proses login.

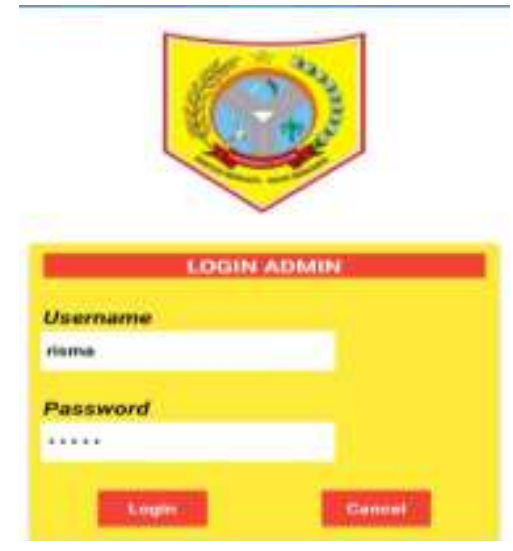

Gambar 8. Tampilan Halaman Login

\section{c. Tampilan Halaman Pengolahan Data Penduduk}

Pada halaman ini, admin dapat melakukan pengolahan data penduduk meliputi view, input, edit dan delete.

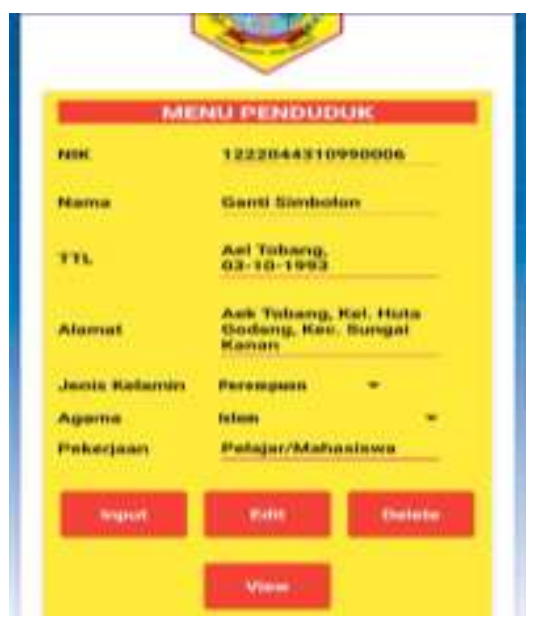

Gambar 9. Tampilan Halaman Pengolahan Data Penduduk

\section{d. Tampilan Halaman Informasi Penduduk}

Pada halaman ini, user dapat memilih dan melihat informasi penduduk berdasarkan NIK yang sebelumnya telah di proses.

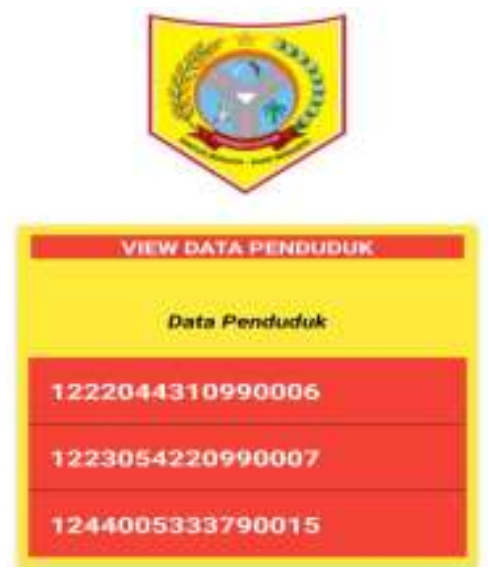

Gambar 10. Tampilan Halaman Informasi Penduduk

\section{e. Tampilan Halaman Rinci Data Penduduk}

Pada halaman ini, user dapat melihat data penduduk secara rinci dengan memilih data penduduk berdasarkan NIK yang telah dipilih. 


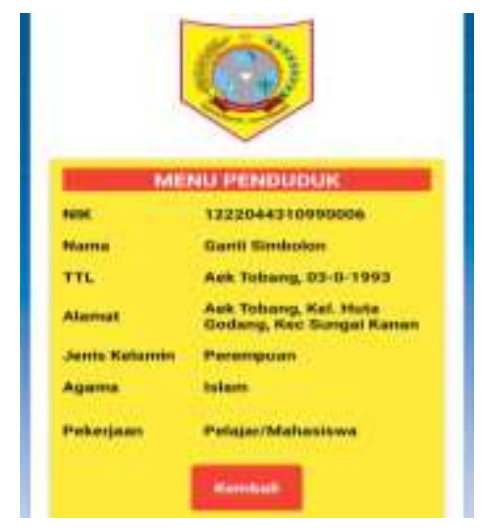

Gambar 10. Tampilan Halaman Informasi Penduduk

\section{KESIMPULAN}

Setelah melakukan penelitian ini, maka penulis mengambil kesimpulan dari kegiatan penelitian yang telah dilakukan. Kesimpulan tersebut antara lain :

1. Sistem informasi kependudukan yang telah bangun dapat menggantikan sistem kependudukan yang masih dilakukan dengan menggunakan aplikasi Microsoft Excel menjadi sistem informasi kependudukan secara online dengan menggunakan smartphone android

2. Sistem informasi kependudukan yang dibangun dapat memudahkan admin kantor desa dalam melakukan pengolahan data penduduk secara cepat dan mudah melalui smartphone android

3. Sistem informasi kependudukan yang dibangun dapat membantu kepala desa atau bagian lainnya pada kantor desa sungai kanan dalam memperoleh informasi penduduk secara rinci

4. Sistem informasi yang dibangun telah disesuaikan dengan spesifikasi smartphone android yang digunakan oleh masyarakat, , sehingga tidak ada kendala pada saat proses instalasi dan penggunaan aplikasi

\section{REFERENCES}

[1] A. Syahrani and D. M. Hutripa, "PERANCANGAN APLIKASI PENDATAAN KELUARGA BERBASIS ANDROID (Studi Kasus: BKKBN Kota Padang)," J. Teknoif, vol. 5, no. 2, pp. 88-96, 2017.

[2] B. Huda, "SISTEM INFORMASI DATA PENDUDUK BERBASIS ANDROID DAN WEB MONITORING STUDI KASUS PEMERINTAH KOTA KARAWANG (Penelitian dilakukan di Kab. Karawang)," BUANA ILMU, vol. 3, no. 1, pp. 62-69, Nov. 2018.

[3] E. Y. A. \& R. Irviani., Pengantar Sistem Informasi. Yogyakarta: CV. Andi Offset, 2017.

[4] M. K. Dr. H. A. Rusdiana dan Moch. Irfan, Sistem Informasi Manajemen. Bandung: Pustaka Setia, 2014.

[5] A. Kusumawati, tacbir hendro Pudjiantoro, and D. Nursantika, "Sistem Informasi Kependudukan pada kecamatan kadungora kabupaten garut," in Prosiding Seminar Nasional Komputer dan Informatika (SENASKI), 2017, vol. 2017.

[6] A. Budiman and J. Triono, "Sistem Informasi Parkir Kendaraan Bermotor Berbasis Android," J. Ilm. Ilmu-ilmu Tek., vol. 1, no. February, pp. 42-49, 2016.

[7] Nazarudin Safaat, Pemrograman Aplikasi Mobile Smartphone dan Tablet PC Berbasis Android. Bandung: Informatika, 2012.

[8] S. Pradhana, Angga Yudha and J. Lemantara, "Rancang Bangun Aplikasi Analisis Data Keluarga Miskin Berdasarkan Kriteria Badan Pusat Statistik (BPS) Di Desa Banaran Kabupaten Kediri," vol. 5, no. 11, pp. 1-6, 2016.

[9] M. Sihaloho, E. Sri Wahyuni, and R. A. Kinseng, "Perubahan Struktur Agraria, Kemiskinan, Dan Gerak Penduduk: Sebuah Tinjauan Historis," Sodality J. Sosiol. Pedesaan, vol. 4, no. 1, 2016.

[10] A.S. Rosa dan Shalahudin, Rekayasa Perangkat Lunak (Terstruktur dan Berorientasi Objek ). Bandung: Informatika, 2015. 